\title{
BODY OF KNOWLEDGE IN RESEARCH OF AIR TRAFFIC MANAGEMENT: CASE STUDY IN INDONESIA
}

\author{
Neno Ruseno ${ }^{1}$, Mahardi Sadono ${ }^{2}$ \\ ${ }^{1}$ Aviation Engineering of IULI, MyRepublic Plaza, $5^{\text {th }}$ Floor, The Breeze, BSD City 15345 , \\ Indonesia, email: neno.ruseno@iuli.ac.id \\ ${ }^{2}$ Aeronautical Engineering of ITB, J1. Ganesha No. 10, Labtek II, $4{ }^{\text {th }}$ Floor, Bandung 40132 , \\ Indonesia
}

\begin{abstract}
Air Traffic Management (ATM) is a discipline that manages the movement of flights in the air and on the ground. Its functions are to maintain the safety level required by the authority and to provide the capacity required by the airlines. The challenges in ATM come from the in-balance between the market growth and the available infrastructure and also the gap between the regulations and the technology. The research in ATM provides the solutions by introducing new methods or technologies to cope with those challenges.

The effort in organizing and cataloging the Body of Knowledge (BOK) in research of ATM is presented in this report. This BOK is a complete set of research concepts and activities in term of managing the air traffic to improve the air transportation safety and its capacity. Considering the latest publications in the last 5 years, the BOK consists of five areas of operation which are enroute, arrival, terminal, departure and connectivity. Each area of operations consists of several knowledge units that contain several research topics. In this report, a special attention is given to the development of ATM research in Indonesian. It characterizes with the challenges that commonly faced in Indonesia such as high density air traffic, in-sufficient infrastructure/technology, in-balance demand and supply during peak hours and major disruption by natural disasters (volcanoes and earth quakes).

The report summarizes that the trend of ATM research in Indonesia is in the knowledge unit of capacity optimization. Additionally, it recommends to explore research activities by implementing new air traffic concepts such as the trajectory based operation and the integrated of departure and arrival management to improve capacity, efficiency and safety.
\end{abstract}

Key words: Body of Knowledge, Air Traffic Management, Indonesian air transportation, Enroute, Arrival, Terminal, Departure, Connectivity

\section{Introduction}

Air Traffic Management (ATM) is one of the components in aviation industry that mainly related with the movement of flights that includes departing from an airport, cruising in airspace and arriving on a destination airport. Current ATM emphasize on harmonization and interoperability systems that allow smooth transition of flight operations from one stage of operation to the next stage of operation and also from an airspace to the next airspace.

The challenges in ATM come from the in-balance between the market growth and the available infrastructure and also the gap between the regulations and the technology. The research in ATM will provide the solutions by introducing new methods or technologies to cope with those challenges. Currently, there are two major research projects that aim to prepare the ATM to cope with the future challenges. They are Next Generation (NextGen) 
project in United States and Single European Sky ATM Research (SESAR) project in Europe [1]-[5].

Indonesia is one of the countries that enjoying the steady growth of its air transportation industry in this decade. Its geographic location, its population and its economic development are the main factors supporting this phenomenon. However, the limited infrastructure, the decades old air traffic control system and its man power capability limits the further growth. Increasing flight delay, longer flight route and long aircraft queue during takeoff and landing are several parameters that indicate the overall ATM system needs to be upgraded [6].

Upgrading ATM system will require contributions from all stakeholders. Indonesian government started the ATM upgrading with the Indonesian Modernization Air Navigation Services (IMANS) project. This project updates communication, ground navaid, PBN procedure and surveillance systems [7]. Research and academic community as one of the ATM stakeholders in Indonesia also needs to be involved by introducing an innovation in ATM technology to solve the issues facing by the operator.

The Body of Knowledge (BOK) in ATM research could guide the research community in Indonesia to define research topics that related with the future challenges. It also could assist the Air Navigation Service Provider (ANSP) in Indonesia which is AirNav Indonesia in selecting the ATM technologies that suitable to be implemented in Indonesia.

This report aims to classify the research topics in global ATM and identify the key topics that could significantly contribute to the development of ATM in Indonesian. It will start with the collection and classification of research topics in ATM based on the five areas of operation which are enroute, arrival, terminal, departure and connectivity. A special attention will be given to the development of ATM research in Indonesian. It will consider the special characteristics that relates to the challenges commonly faced in Indonesia. The summary will recommend the research area and topics that could provide significant benefits for ATM development in Indonesia.

\section{Process for Classification of ATM Research}

The author is planning to conduct a $\mathrm{PhD}$ research in area of Air Traffic Management and trying to formulate the most suitable research topic that could benefited for Indonesia air transportation development. However, I am not found any publications that highlight the classification of research area in ATM. Thus, the author got an idea from the BOK of other are such as Software Engineer [8], [9] and Project Management [10]. The BOK will consist of hierarchy description and decomposition of research area in ATM.

The development process of BOK is explained in 4 steps as shown in figure 1. It starts with the collecting the published research in the last 5 years to get the most up to date research activities. The source of research publication ranged from an open source publication search engine such as Google Scholar, Journal website, Conference website and also social media type research sharing platform such as Research Gate and Academia.

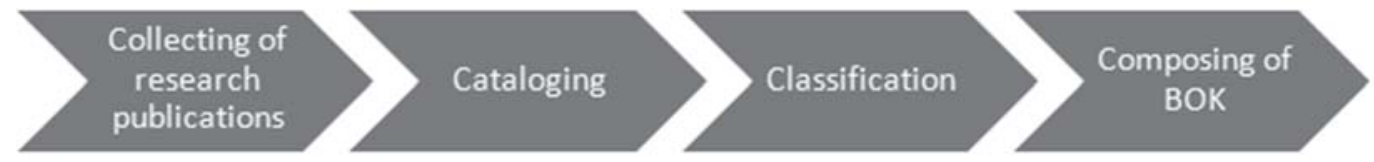

Figure 1. The development process of ATM research BOK.

It continues with cataloging the collected research publications. There are very wide research topics and it is very challenging to classify it based on the purpose or the result. On this stage, we collected the topic of research, the purpose, the method, the result and also the 
summary. From this catalogue, it is more clearer the similarity and dissimilarity between them. Beside research publications there are also documents that aggregate the research activities such as documentation from SESAR and NextGen projects [1]-[5]. These documents give more general idea on the research area currently explored.

The next step is to classify the research activities in ATM. This BOK is classified as a hierarchy in 4 levels as shown in figure 2. The BOK is divided into several area of operation. Each area of operation consists of several knowledge units. The knowledge unit is expanded into several research topics.

The last step is the composing of BOK which gives the full hierarchy on each of the categories. It is supplied with the description of each category and it will be explained in the next chapter.

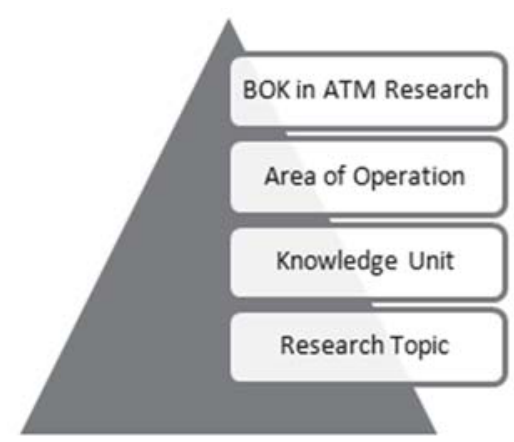

Figure 2. The hierarchy of ATM Research BOK.

\section{BOK of ATM Research}

Air Traffic Management (ATM) is a discipline that manages the movement of flights in the air and on the ground starting from the origin airport to the destination airport. Its functions are to maintain the safety level required by the authority and to provide the capacity required by the airlines. Basically, the ATM can be classified into several areas of operation based on the flight segments such as enroute, arrival, terminal and departure. Since a research in ATM tries to solve a traffic issue or to implement an innovation to improve a traffic condition at specific flight segment, the ATM research also can be classified based on the flight segments.

First, enroute or cruising flight segment is the biggest portion of a flight in term of time and distance. For long haul flight, it could cross several airspaces belong to different countries. The smooth handover between airspace controllers is a key factor in harmonizing global ATM.

The second area of operation is the arrival. It requires a separation between flights that fulfills the safety margin and at the same time provides a sufficient runway capacity. A new method in arrival which is the continuous descent operation has a potential to reduce the fuel consumption and noise produced. However, its implementation during peak hours is still in question.

The third area of operation is the terminal segment which is the ground part of a flight. In-balance of traffic during peak hours and non-peak hours is one of major issues. Furthermore, the uncertainty in visibility requires a new surveillance technology to improve the safety level.

The last area of operation is the departure segment which is considered as less complicated than the arrival. However, the integrated of departure and arrival management could improve the coordination in handling incoming and outgoing flight to improve the capacity and minimize delay time. 
In addition to the flight segments, the communication between airside and ground side and also between each of them is also an important mode in ATM which needs to be addressed. With the advance in information technology, the communication is not limited to a voice, but also with a direct data link. The data link allows the usage of automation on aircraft monitoring and surveillance. Thus we can add a new classification of ATM research as connectivity.

The complete area of operation and its knowledge unit are shown in figure 3. It will be explained more detail in the coming chapters. Since this BOK in ATM Research is the first of such document, comments and suggestions are welcome for future revision.

\subsection{Enroute}

Enroute is one of the ATM operation areas that relate with the usage of middle and upper part of airspace. It is mainly for the cruising segment of a flight that normally above altitude of FL100. Actually, it is the majority portion of a flight in term of flight time and fuel consumption. From airline view, all flights need to be flown at their optimum altitude and shortest route. However, with the growth of air traffic, accommodating the optimum flight profile become very challenging. The airspace needs to be optimized to improve the capacity and safety. In this area of operation, the published research can be categorized into three different research areas as explained in table 1.

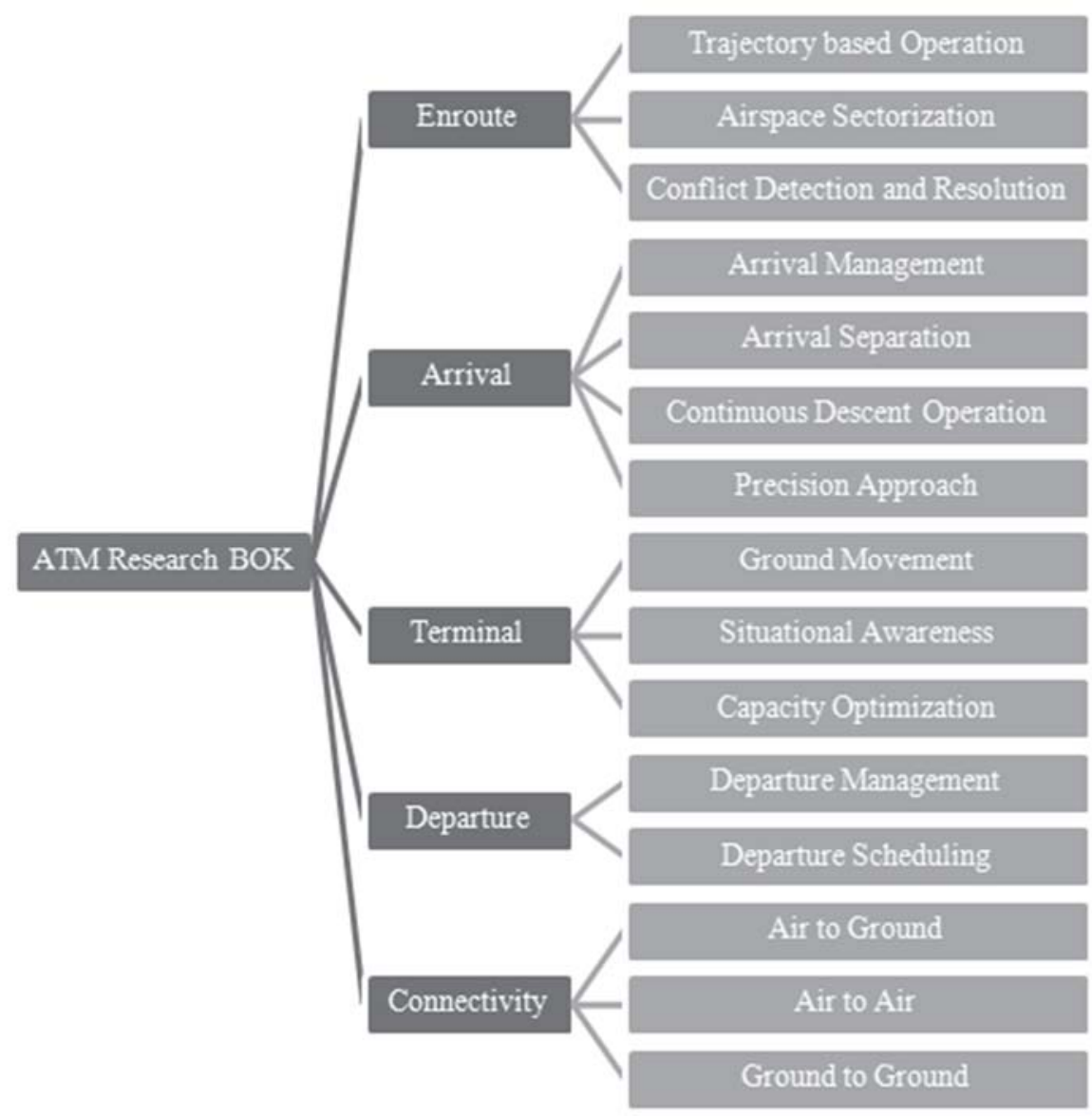

Figure 3. The area of operations and knowledge units in ATM research. 
Table 1. Research Classification in Enroute operation area.

\begin{tabular}{|c|c|}
\hline Knowledge Unit & 1. Trajectory based operation \\
\hline Description & $\begin{array}{l}\text { It is the concept of improving throughput, flight efficiency, flight } \\
\text { times and schedule predictability through better prediction and } \\
\text { coordination of aircraft trajectories. It could employ trajectory-based } \\
\text { automation, air/ground data link, and higher levels of automation for } \\
\text { separation assurance to increase airspace capacity. }\end{array}$ \\
\hline $\begin{array}{l}\text { Example of Research } \\
\text { Topics }\end{array}$ & $\begin{array}{l}\text { An Oceanic Trajectory Based Operations Concept Shaped by } \\
\text { Operational Influences. [11] } \\
\text { Flight Trajectory Optimization Through Genetic Algorithms for } \\
\text { Lateral and Vertical Integrated Navigation. [12] }\end{array}$ \\
\hline Knowledge Unit & 2. Airspace sectorisation \\
\hline Description & $\begin{array}{l}\text { Airspace sectorisation provides a partition of a given airspace into } \\
\text { sectors, subject to geometric constraints and working constraints, so } \\
\text { that some cost metric is minimised. Opening/closing of sectors should } \\
\text { closely monitor the demand to achieve efficient use of all available } \\
\text { resources. }\end{array}$ \\
\hline $\begin{array}{l}\text { Example of Research } \\
\text { Topics }\end{array}$ & $\begin{array}{l}\text { CDAS: A Cognitive Decision-Making Architecture for Dynamic } \\
\text { Airspace Sectorization for Efficient Operations. [13] } \\
\text { A multi-objective approach for 3D airspace sectorization: A study on } \\
\text { Singapore regional airspace. [14] }\end{array}$ \\
\hline Knowledge Unit & 3. Conflict detection and resolution \\
\hline Description & $\begin{array}{l}\text { The conflict situation between aircrafts is detected on the basis of } \\
\text { forecast of their motion, and parameters of the conflict. When a } \\
\text { potential conflict is detected, then a resolution must be realized by } \\
\text { manoeuvre of only one aircraft or both of them in the conflicting pair. }\end{array}$ \\
\hline $\begin{array}{l}\text { Example of Research } \\
\text { Topics }\end{array}$ & $\begin{array}{l}\text { Review: Analysis and Improvement of Traffic Alert and Collision } \\
\text { Avoidance System. [15] } \\
\text { A flexible framework for solving the air conflict detection and } \\
\text { resolution problem using maximum cliques in a graph. [16] }\end{array}$ \\
\hline
\end{tabular}

\subsection{Arrival}

It is the descending traffic toward the destination airports. It could start from cruise altitude until the aircraft lands on the runway. Arrival segment, especially the approach and landing part is considered as the most critical part of flight in term of safety because many major accidents happens in this segment. The other concern in landing is about the traffic capacity that defines by the separation applied between flights. In addition, the noise produced during landing becomes one of the issues in developed countries. In this area of operation, the published research can be categorized into four different research areas as explained in table 2. 
Table 2. Research Classification in Arrival operation area.

\begin{tabular}{|c|c|}
\hline Knowledge Unit & 1. Arrival Management \\
\hline Description & $\begin{array}{l}\text { Arrival Management (AMAN) is designed to provide automated } \\
\text { sequencing support for handling traffic arriving at an airport. It will } \\
\text { continuously calculating arrival sequences and times for flights, taking } \\
\text { into account the locally defined landing rate, the required spacing for } \\
\text { flights arriving to the runway and other criteria. AMAN makes use of } \\
\text { the available capacity at an airport combined with a more efficient and } \\
\text { predictable traffic. It can assist in reducing low altitude holding and } \\
\text { tactical intervention from ATC that can lead to lower fuel } \\
\text { consumption, less noise and emission. }\end{array}$ \\
\hline $\begin{array}{l}\text { Example of Research } \\
\text { Topics }\end{array}$ & $\begin{array}{l}\text { Integrating Arrival Management with Airspace Design and Analysis. } \\
{[17]} \\
\text { Analysis on the Impact of Pop-Up Flight Occurrence when Extending } \\
\text { the Arrival Management Horizon. [18] }\end{array}$ \\
\hline Knowledge Unit & 2. Arrival Separation \\
\hline Description & $\begin{array}{l}\text { Arrival separation is the concept of keeping an aircraft outside a } \\
\text { minimum distance from another aircraft in an arrival traffic to reduce } \\
\text { the risk of those aircraft colliding, as well as prevent accidents due to } \\
\text { secondary factors such as wake turbulence. For an aircraft following } \\
\text { the same tracks, longitudinal separation may be achieve by requiring } \\
\text { aircraft to make position reports and comparing the time of their } \\
\text { reports or by speed control, ensuring that the speed of the following } \\
\text { aircraft does not exceed the speed of the leading aircraft. }\end{array}$ \\
\hline $\begin{array}{c}\text { Example of Research } \\
\text { Topics }\end{array}$ & $\begin{array}{l}\text { ECAC Use Case of Optimised Pre-tactical Time of Arrival } \\
\text { Adjustments to Reduce Probability of Separation Infringements. [19] } \\
\text { Optimal Arrival Time Assignment and Control Analysis using Air } \\
\text { Traffic Data for Tokyo International Airport. [20] }\end{array}$ \\
\hline Knowledge Unit & 3. Continuous Descent Operation \\
\hline Description & $\begin{array}{l}\text { Continuous Descent Operation (CDO) is an aircraft operating } \\
\text { technique in which an arriving aircraft descends from an optimal } \\
\text { position with minimum thrust and avoids level flight to the extent } \\
\text { permitted by the safe operation of the aircraft and compliance with } \\
\text { published procedure and ATC instructions. The objective of a CDO is } \\
\text { to reduce aircraft noise, fuel burn and emissions. The ideal CDO starts } \\
\text { at the top of descent and ends when the aircraft starts the final } \\
\text { approach and follows the glide slope of the runway. }\end{array}$ \\
\hline $\begin{array}{c}\text { Example of Research } \\
\text { Topics }\end{array}$ & $\begin{array}{l}\text { Study of Point Merge technique for efficient Continuous Descent } \\
\text { Operations in TMA. [21] } \\
\text { Research on Trajectory Generation and Optimization in Continuous } \\
\text { Descent Operations. [22] }\end{array}$ \\
\hline Knowledge Unit & 4. Precision Approach \\
\hline Description & $\begin{array}{l}\text { Precision approach is an instrument approach and landing using } \\
\text { precision lateral and vertical guidance with minima as determined by } \\
\text { the category of operation. The guidance is provided by a ground based }\end{array}$ \\
\hline
\end{tabular}




\begin{tabular}{|c|l|}
\hline & $\begin{array}{l}\text { navigation aids, computer generated navigation data or a controller } \\
\text { interpreting the display. The categories of precision approach and } \\
\text { landing are defined according to the applicable decision height or } \\
\text { visibility. On reaching the decision height, the pilot may continue the } \\
\text { approach to land provided the required visual reference or commence } \\
\text { a missed approach procedure. }\end{array}$ \\
\hline $\begin{array}{c}\text { Example of Research } \\
\text { Topics }\end{array}$ & $\begin{array}{l}\text { Geometric approach for RNP transition to xLS procedure design. [23] } \\
\text { Automatic speed profiling and automatic landings during advanced } \\
\text { RNP to xLS flight tests. [24] }\end{array}$ \\
\hline
\end{tabular}

\subsection{Terminal}

It is the ground movement of aircraft out of the runway toward the terminal gate/parking area and from the terminal gate/parking area toward the runway. In a large airport, the taxiway configuration allows for optimization in ground flow movement considering the shortest route or the less fuel consumption. However, the optimized route could complicate the ground traffic due to the difference of each aircraft taxi route. The safety could deteriorate when the poor visibility happens. Some new technique and technology such as ADS-B or Radar could be used to improve the situational awareness of traffic during taxi in low visibility. In this area of operation, the published research can be categorized into three different research areas as explained in table 3.

Table 3. Research Classification in Terminal operation area.

\begin{tabular}{|c|c|}
\hline Knowledge Unit & 1. Ground Movement \\
\hline Description & $\begin{array}{l}\text { It involves all aspect of aircraft handling at airports as well as aircraft } \\
\text { movement around the aerodrome. It needs to consider the smooth } \\
\text { operation and safety aspect. }\end{array}$ \\
\hline $\begin{array}{l}\text { Example of Research } \\
\text { Topics }\end{array}$ & $\begin{array}{l}\text { Real-time airport surface movement planning: Minimizing aircraft } \\
\text { emissions. [25] } \\
\text { An integrated optimisation approach to airport ground operations to } \\
\text { foster sustainability in the aviation sector. [26] }\end{array}$ \\
\hline Knowledge Unit & 2. Situational Awareness \\
\hline Description & $\begin{array}{l}\text { Situational awareness can be improved with the better sharing of } \\
\text { information that accessible for all stakeholders in a user friendly, } \\
\text { understandable and consistent format. It helps planning the resources } \\
\text { on a daily basis and supports decision making in bad weather } \\
\text { conditions. }\end{array}$ \\
\hline $\begin{array}{l}\text { Example of Research } \\
\text { Topics }\end{array}$ & $\begin{array}{l}\text { Conducting Safe and Efficient Airport Surface Operations in a } \\
\text { NextGen Environment. [27] } \\
\text { A Runway Incursion Detection Approach Based on Multiple } \\
\text { Protected Area and Flight Status Machine for A-SMGCS. [28] }\end{array}$ \\
\hline Knowledge Unit & 3. Capacity Optimization \\
\hline Description & $\begin{array}{l}\text { A major goal of air traffic management is to strategically control the } \\
\text { flow of traffic so that the demand at an airport meets but does not } \\
\text { exceed the operational capacity. It needs to consider both the arrival } \\
\text { and departure operations as an interdependent process. }\end{array}$ \\
\hline
\end{tabular}




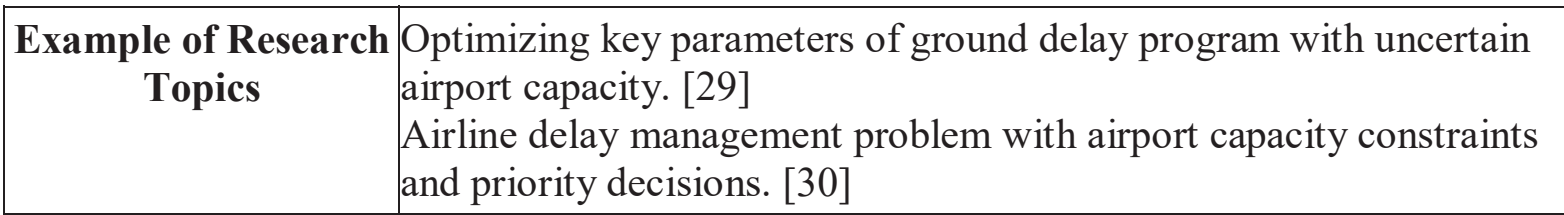

\subsection{Departure}

It is the departed traffic from the runway to join the cruising segment. It includes takeoff and climb segment which aircraft gain altitude to join the enroute segment. Since the departure traffic is diverge at the end, this segment is less challenging compare to other flight segments. However, an optimization could be used to improve the runway capacity. Furthermore, integration with arrival management at the destination airport could benefit in reducing holding by departure delay and avoiding diversion or return to base flight. In this area of operation, the published research can be categorized into two different research areas as explained in table 4.

Table 4. Research Classification in Departure operation area.

\begin{tabular}{|c|c|}
\hline Knowledge Unit & 1. Departure Management \\
\hline Description & $\begin{array}{l}\text { Departure management (DMAN) is a planning tool developed to } \\
\text { improve the departure flows at airports and increase the traffic } \\
\text { predictability. DMAN calculate the target takeoff time taking } \\
\text { multiple constraints and preference into account. It provided a } \\
\text { planned departure flow with the goal to maintain an optimal } \\
\text { throughput at the runway, reduce queuing at holding point and } \\
\text { distribute the information to various stakeholders at the airport. }\end{array}$ \\
\hline $\begin{array}{l}\text { Example of Research } \\
\text { Topics }\end{array}$ & $\begin{array}{l}\text { Comparison of First-Come First-Served and Optimization Based } \\
\text { Scheduling Algorithms for Integrated Departure and Arrival } \\
\text { Management. [31] } \\
\text { Management of Time Based Taxi Trajectories coupling Departure } \\
\text { and Surface Management Systems. [32] }\end{array}$ \\
\hline Knowledge Unit & 2. Departure Scheduling \\
\hline Description & $\begin{array}{l}\text { Departure scheduling needs to consider wake-separation constraints } \\
\text { for successive departures, miles-in-trail separation for aircraft bound } \\
\text { for the same departure fixes, and time-window or prioritization } \\
\text { constraints for individual flights. Besides these, emissions as well as } \\
\text { increased fuel consumption due to inefficient scheduling need to be } \\
\text { included. The aims are to improve efficiency and throughput of } \\
\text { overall surface operations at busy airports }\end{array}$ \\
\hline $\begin{array}{l}\text { Example of Research } \\
\text { Topics }\end{array}$ & $\begin{array}{l}\text { A bi-objective integer programming model for partly-restricted flight } \\
\text { departure scheduling. [33] } \\
\text { A two-stage no-wait hybrid flow-shop model for the flight departure } \\
\text { scheduling in a multi-airport system. [34] }\end{array}$ \\
\hline
\end{tabular}

\subsection{Connectivity}

Connectivity is a new communication mean that connects different actors in air traffic management. In the latest development, it includes direct communication between aircraft and ground systems using data link. This allows for implementation of more automation and 
automatic monitoring that could improve the capacity and safety level. In this area of operation, the published research can be categorized into three different research areas as explained in table 5.

Table 5. Research Classification in Connectivity operation area.

\begin{tabular}{|c|c|}
\hline Knowledge Unit & 1. Air to Ground \\
\hline Description & $\begin{array}{l}\text { It is the means by which the ground systems or the ground personals } \\
\text { communicate with the airborne systems or the flight crew }\end{array}$ \\
\hline $\begin{array}{c}\text { Example of Research } \\
\text { Topics }\end{array}$ & $\begin{array}{l}\text { How much is too much on monitoring tasks? Visual scan patterns of } \\
\text { single air traffic controller performing multiple remote tower } \\
\text { operations. [35] } \\
\text { In-Flight Broadband Connectivity: Architectures and Business Models } \\
\text { for High Capacity Air-to-Ground Communications. [36] }\end{array}$ \\
\hline Knowledge Unit & 2. Air to Air \\
\hline Description & $\begin{array}{l}\text { It is the means by which the airborne systems or the flight crew } \\
\text { communicate with the other airborne systems or the flight crew in } \\
\text { different aircraft }\end{array}$ \\
\hline $\begin{array}{c}\text { Example of Research } \\
\text { Topics }\end{array}$ & $\begin{array}{l}\text { A Formally Verified Hybrid System for the Next-Generation Airborne } \\
\text { Collision Avoidance System. [37] } \\
\text { Realities and challenges of NextGen air traffic management: The case } \\
\text { of ADS-B. [38] }\end{array}$ \\
\hline Knowledge Unit & 3. Ground to Ground \\
\hline Description & $\begin{array}{l}\text { It is the means by which the ground systems or the ground personals } \\
\text { communicate with the other ground systems or the other ground } \\
\text { personals }\end{array}$ \\
\hline $\begin{array}{l}\text { Example of Research } \\
\text { Topics }\end{array}$ & $\begin{array}{l}\text { The approach of SWIM data sharing based on multi-dimensional data } \\
\text { encryption. [39] } \\
\text { A Method for SWIM-Compliant Human-in-the-Loop Simulation of } \\
\text { Airport Air Traffic Management. [40] }\end{array}$ \\
\hline
\end{tabular}

\section{ATM Research in Indonesia}

Indonesia is the largest archipelago in the world with more than 17,000 islands requires air transportation to connect each of its cities and communities. With its current population is more than 250 millions, the size of air transportation is 97 million passengers in 2017 [41]. However, there are some special characteristic of air traffic in Indonesia that will be explained in the next section of this report. It will follow with the research development of air traffic management in Indonesia.

\subsection{Air Traffic Characteristics in Indonesia}

There are 4 major characteristics of air traffic in Indonesia which are:

\subsubsection{High density air traffic.}

In the last 5 years, Indonesia experienced double digits growth in air transportation [6]. It is supported by the introduction of low cost carriers and the growth of middle class income. According to a report from AirNav Indonesia, it increases the maximum runway 
capacity in Soekarno Hatta airport up to 84 movements per hour [42]. Another evidence of high traffic density is the Jakarta-Surabaya route ranked the $4^{\text {th }}$ busiest route in the world as 819 flights per week [43].

\subsubsection{In-sufficient infrastructure/technology.}

The rapid growth in air traffic improves the country economical sector. However at certain airports such as Soekarno Hatta airport, the growth is limited by the capacity available. When the capacity is increased further without the sufficient support from infrastructure or technology, the safety level will deteriorate. Currently, there are some new runways, new terminals and new airports project at certain locations to cope with the increasing demand.

\subsubsection{In-balance demand and supply during peak hours and non peak hours.}

The typical demand of air traffic is high at peak hours due to the nature of passenger preference. For example the traffic demand in Juanda airport is above the maximum capacity only during morning peak hours [44]. This trend can be found in other busy airports. One of possible solution is to spread out the demand into the wider period of time.

\subsubsection{Frequent major disruptions due to natural disasters.}

Volcanoes and earth quakes are two phenomenon commonly happen in Indonesia due to its location in "the ring of fire". Many active volcanoes erupted recently such as Mount Agung in Bali, Mount Sinabung in North Sumatera, Mount Gamalama in Ternate and Mount Raung in East Java [45]. Also, the latest earth quake in Lombok this year devastated the city and also disrupts the air traffic around that area.

\subsection{Research development of ATM in Indonesia}

In the last 5 years, I found 14 publications from Indonesian scientist that related with ATM research as shown in table 6. It can be categorized according to this BOK: one publication in enroute, two publications in arrival, seven publications in terminal, one publication in departure and three publications in connectivity.

Table 6. ATM research publications in Indonesia.

\begin{tabular}{|c|c|c|}
\hline $\begin{array}{c}\text { Area of } \\
\text { Operation }\end{array}$ & Publication & Knowledge Unit \\
\hline Enroute & $\begin{array}{l}\text { Sekartadji, R., Ahyudanari, E., \& Jaelani, L. M. } \\
\text { (2017). Analysis of Air Traffic Density using } \\
\text { GIS , Case Study: Jakarta-Surabaya Analysis of } \\
\text { Air Traffic Density using GIS , Case Study: } \\
\text { Jakarta-Surabaya.[43] }\end{array}$ & $\begin{array}{c}\text { Airspace } \\
\text { Sectorisation }\end{array}$ \\
\hline Arrival & $\begin{array}{l}\text { P. R. Aswia et al. (2015). Optimalisasi STAR RNAV } \\
\begin{array}{l}1 \text { menggunakan konsep point of merge di } \\
\text { wilayah terminal airspace bandar udara. }[46]\end{array}\end{array}$ & Arrival Separation \\
\hline Arrival & $\begin{array}{l}\text { I. Setiowati, I. Hasbiyati, and M. D. H. Gamal (2017). } \\
\text { Scheduling Aircraft Landing at Single Runway. } \\
\text { [47] }\end{array}$ & Arrival Management \\
\hline
\end{tabular}




\begin{tabular}{|c|c|c|}
\hline Terminal & $\begin{array}{l}\text { M. L. Caroline, Y. Asnar, and A. I. Kistijantoro. } \\
\text { (2016). Scheduling model for air traffic in } \\
\text { Indonesia. [48] }\end{array}$ & $\begin{array}{l}\text { Capacity } \\
\text { Optimization }\end{array}$ \\
\hline Terminal & $\begin{array}{l}\text { S. Hamzah and S. A. Adisasmita. (2014). Aircraft } \\
\text { parking stands: proposed model for Indonesian } \\
\text { airports. [49] }\end{array}$ & $\begin{array}{c}\text { Capacity } \\
\text { Optimization }\end{array}$ \\
\hline Terminal & $\begin{array}{l}\text { C. W. M. Noor and R. Mamat. (2017). Application of } \\
\text { Artificial Neural Network to Predict the use of } \\
\text { Runway at Juanda International Airport } \\
\text { Application of Artificial Neural Network to } \\
\text { Predict the use of Runway at Juanda } \\
\text { International Airport. [50] }\end{array}$ & $\begin{array}{l}\text { Capacity } \\
\text { Optimization }\end{array}$ \\
\hline Terminal & $\begin{array}{l}\text { F. A. Perdana and R. Moxon. (2014). Traffic } \\
\text { distribution study on Multi-Airport systems in } \\
\text { the Greater jakarta Metropolitan Area (GJMA) } \\
\text { and associated implications. [51] }\end{array}$ & $\begin{array}{c}\text { Capacity } \\
\text { Optimization }\end{array}$ \\
\hline Terminal & $\begin{array}{l}\text { M. I. Rachmansyah and Nahdalina. (2017). Pengaruh } \\
\text { Penyeimbangan Pergerakan Pesawat Terhadap } \\
\text { Peningkatan Kinerja Bandara (Studi Kasus: } \\
\text { Bandara Internasional Soekarno-Hatta). [52] }\end{array}$ & $\begin{array}{c}\text { Capacity } \\
\text { Optimization }\end{array}$ \\
\hline Terminal & $\begin{array}{l}\text { Safrilah and J. C. P. Putra. (2017). Review Study on } \\
\text { Runway Capacity Parameters and Improvement. } \\
{[44]}\end{array}$ & $\begin{array}{l}\text { Capacity } \\
\text { Optimization }\end{array}$ \\
\hline Terminal & $\begin{array}{l}\text { C. Setyarini and E. Ahyudanari. (2017). Analisis } \\
\text { Pengaruh Pergeseran Runway Holding Position } \\
\text { terhadap Runway Occupancy Time dan Runway } \\
\text { Capacity (Studi Kasus: Bandar Udara } \\
\text { Internasional Juanda). [53] }\end{array}$ & $\begin{array}{c}\text { Capacity } \\
\text { Optimization }\end{array}$ \\
\hline Departure & $\begin{array}{l}\text { K. Novianingsih and R. Hadianti. (2014). Modeling } \\
\text { flight departure delay distributions. [54] }\end{array}$ & $\begin{array}{l}\text { Departure } \\
\text { Scheduling }\end{array}$ \\
\hline Connectivity & $\begin{array}{l}\text { A. Bharata. (2017). Perancangan Sistem Pintar } \\
\text { Prediksi Trajektori Pesawat Menggunakan Data } \\
\text { ADS-B dengan Metode Kalman Filter untuk } \\
\text { Mencegah Collision. [55] }\end{array}$ & Air to Ground \\
\hline Connectivity & $\begin{array}{l}\text { S. Nugraha and A. T. Caesar. (2016). Analisis Kinerja } \\
\text { Sistem Doppler VHF Omnidirectional Range } \\
\text { dan Distance Measuring Equipment pada } \\
\text { Navigasi Penerbangan. [56] }\end{array}$ & Air to Ground \\
\hline Connectivity & $\begin{array}{l}\text { Y. Nurhayati and Susanti. (2014). The } \\
\text { Implementasion of Automatic Dependent } \\
\text { Surveillance Broadcast ( ADS-B in Indonesia). } \\
\text { [57] }\end{array}$ & Air to Ground \\
\hline
\end{tabular}

In the enroute area of operation, the reseach analyzes the air traffic density for JakartaSurabaya route which is one of the busiest routes in the world [43]. The current traffic data is used to predict the future density of this route considering the development of new runways 
and airports in that airspace sector. The knowledge unit of trajectory based operation is not yet explored and further conflict detection and resolution could improve the safety level.

The two publications in arrival area of operation consist of one publication in arrival separation and another one in arrival management. The first publication proposed an application of point merge technique for arrival separation in STAR RNAV 1 procedure in Soekarno Hatta airport. Based on the simulation, it could reduce the ATC workload and communication by 20\%. Also it can save 3-5 minutes of flight time [46]. The second research developed a mathematical model for landing scheduling to minimize the overall flight time [47]. Both of the research emphasize on maximize the capacity available by managing the arrival flow more evenly. The knowledge unit of continuous descent operation and precision approach are not explored yet.

The seven publications in terminal area of operations emphasize on airport capacity optimization from different point of view. The first four publications optimized the runway utilization in order to improve the airport capacity [44], [48], [50], [53]. The fifth publication improved airport capacity by optimization of parking stand and apron model [49]. The sixth publication optimized airport capacity by the traffic distribution of multi airport system in greater Jakarta area [51]. The last publication proposed of using bigger aircrafts for domestic routes to increase the airport passenger capacity [52]. The knowledge unit of situational awareness is not explored yet.

The only publication in departure area of operation used genetic algorithm to predict departure delay and analyze its effect on the schedule sensitivity. Thus airline can develop a schedule that robust to the departure delay [54].

In the operation area of connectivity, there are three publications that focused on air to ground connection. The first and second publication analyze the implementation of ADS-B which the former use it for collision avoidance and the later for surveillance [55], [57]. The last publication analyze the DVOR signal modulation used for flight navigation [56]. The knowledge units of connection between air to air and ground to ground are not yet explored.

Thus, the trend of ATM research in Indonesia is the capacity optimization for enroute, departure, arrival and terminal area of operation. This trend is very reasonable because the major issue in Indonesia's air traffic is the in-balance between capacity and demand. The air transportation industry growth very high but the infrastructure development is slow.

\subsection{Potential ATM Research for Indonesia}

There is a huge gap between ATM research in global especially US and Europe compare to Indonesia. There are many new ATM concepts that can be adopted to improve the Indonesian air traffic. Some of them are free route and Trajectory Based Operation (TBO) in enroute, Continuous Descent Operation (CDO) in arrival, integrated Departure and Arrival Management (D-AMAN) and System Wide Information Management (SWIM) concept for connectivity

The free route concept was started to be implemented in some European airspaces. This concept allows for more direct route that lead to shorter flight time and saving fuel consumption. However this implementation requires a validation system that avoids any conflicts during the planning and conflict, detection and resolution system to mitigate the possible conflicts [3]. This concept can be used to optimize the airspace capacity instead of using high density fix route such as the case for Jakarta-Surabaya route.

The Trajectory Based Operation (TBO) concept allows each flight to have its own optimum trajectory. It means that each flight has its own optimum 4D trajectory (location, altitude and time) that updated continuously. It requires a data link connection between all traffic with the ground controller systems. This concept could improve capacity, flight efficiency and schedule predictability [3]. Since flight delay is very common in Indonesia, the 
implementation of this concept could improve the on-time performance through the better prediction and coordination of flight trajectories.

The concept of Continuous Descent Operation (CDO) allows for less fuel burn and less noise due to the idle engine setting used and no step descent segments. However, it requires a spacing monitoring system to make sure that the separation is not below the minimum safety margin. That is the reason that currently in Europe this concept only implemented during low density traffic. In Indonesia, CDO is not very interesting research because reducing emission and noise are not the top priority in the aviation regulation yet.

The integrated departure and arrival management allows for accurate runway sequencing but requires close controller coordination between departure and arrival flights. However it could lead to increase in runway capacity and flight efficiency [3]. This coordination concept is a better solution for a busy airport such as Soekarno-Hatta airport, Denpasar airport and Juanda airport.

The SWIM concept allows sharing information and seamless data access and interchange between all stakeholders. It encourages interoperability and standardization of data that enable user and provider to exchange data without different protocol [3]. This concept is not mature yet and requires new information technology infrastructure that support this functionality.

From those new ATM concepts, the trajectory based operation and integrated of departure and arrival management could be the top choices to be adopted in Indonesia. It could allow for improvement in capacity, efficiency and safety with less supporting requirements. Furthermore, the free route, CDO, and SWIM are less suitable for current ATM situation in Indonesia. It is because requires additional advance system to support its implementation and also not yet required by the regulations.

\section{Summary}

The development of a BOK requires a comprehensive process start from collecting the publications from several sources, cataloging the main information and classifying it according to the hierarchy. The hierarchy used in this BOK consists of operation area, knowledge unit and research topic. The resulted BOK in ATM research is an effective way to map the research activities and to look for the latest research trend. It can also be used to define the research area that are not explored yet and have the opportunity to be explored more.

In the case of ATM research in Indonesia, the research trend is in the knowledge unit of traffic capacity optimization for most of the operation area. It is due to the in-balance between capacity and demand of air traffic in Indonesia today. In addition, there are only a few research conducted in enroute and departure. The suggestion for future research is to implement the new air traffic concepts such as trajectory based operation and integrated of departure and arrival management to improve the capacity, efficiency and safety.

\section{References}

[1] F. A. Administration, "NextGen Implementation Plan 2016," 2016.

[2] N. A. Ipt, J. Mcconville, C. May, M. Ellen, M. Raytheon, and R. H. Systems, "Comparison of the SESAR and NextGen Concepts of Operations," 2008.

[3] S. Joint Undertaking, SESAR SOLUTIONS CATALOGUE. 2017.

[4] C. C. for the U.-E. M. A. 1 H.-L. Committee, NextGen - SESAR: State of Harmonisation. 2016.

[5] S. Joint Undertaking, European ATM Master Plan. 2015.

[6] "Indonesia's aviation sector sees double-digit passenger growth for 2018," The Straits Times Singapore, 2017. . 
[7] ICAO, "INDONESIAN CNS/ATM UPDATE," 2017.

[8] T. B. Hilburn, I. Hirmanpour, S. Khajenoori, R. Turner, and A. Qasem, "A Software Engineering Body of Knowledge Version 1. 0," no. April, 1999.

[9] I. C. Society, Guide to the Software Engineering Body of Knowledge Version 3.0 (SWEBOK Guide V3.0). .

[10] PMI, A Guide to the Project Management Body of Knowledge, vol. 5. 2013.

[11] A. Fernandes and J. Rebollo, "An Oceanic Trajectory Based Operations Concept Shaped by Operational Influences," Proc. Hum. Factors Ergon. Soc. Annu. Meet., vol. 60, no. 1, pp. 66-70, Sep. 2016.

[12] R. S. F. Patrón and R. M. Botez, "Flight Trajectory Optimization Through Genetic Algorithms for Lateral and Vertical Integrated Navigation," J. Aerosp. Inf. Syst., vol. 12, no. 8, pp. 533-544, 2015.

[13] C. S. Y. Wong, S. Sundaram, and N. Sundararajan, "CDAS: A Cognitive DecisionMaking Architecture for Dynamic Airspace Sectorization for Efficient Operations," IEEE Trans. Intell. Transp. Syst., pp. 1-10, 2018.

[14] C. W. S. Yin, T. K. Venugopalan, and S. Suresh, "A multi-objective approach for 3D airspace sectorization: A study on Singapore regional airspace," in 2016 IEEE Symposium Series on Computational Intelligence (SSCI), 2016, pp. 1-8.

[15] J. Tang, "Review: Analysis and Improvement of Traffic Alert and Collision Avoidance System," IEEE Access, vol. 5, pp. 21419-21429, 2017.

[16] T. Lehouillier, J. Omer, F. Soumis, and G. Desaulniers, "A flexible framework for solving the air conflict detection and resolution problem using maximum cliques in a graph," Proc. 11th USA/Europe Air Traffic Manag. Res. Dev. Semin. ATM 2015, no. June, 2015.

[17] R. M. Sgorcea, M. Bush, and R. Huleatt, "Integrating Arrival Management with Airspace Design and Analysis," in 17th AIAA Aviation Technology, Integration, and Operations Conference, American Institute of Aeronautics and Astronautics, 2017.

[18] A. Vanwelsenaere, J. Ellerbroek, J. M. Hoekstra, and E. Westerveld, "Analysis on the Impact of Pop-Up Flight Occurrence when Extending the Arrival Management Horizon," Eur. Air Traffic Manag. Res. Dev. Semin., no. June, 2017.

[19] D. Gatsinzi, F. J. Saez Nieto, and I. Madani, "ECAC Use Case of Optimised Pre-tactical Time of Arrival Adjustments to Reduce Probability of Separation Infringements," IFAC-PapersOnLine, vol. 51, no. 9, pp. 186-192, 2018.

[20] Y. Higuchi, N. Kitazume, K. Tamura, T. Kozuka, Y. Miyazawa, and M. Brown, "Optimal Arrival Time Assignment and Control Analysis using Air Traffic Data for Tokyo International Airport," in AIAA Guidance, Navigation, and Control Conference, American Institute of Aeronautics and Astronautics, 2017.

[21] A. Errico and V. Di Vito, "Study of Point Merge technique for efficient Continuous Descent Operations in TMA," IFAC-PapersOnLine, vol. 51, no. 9, pp. 193-199, 2018.

[22] J. Liu, J. Zhang, X. Dai, and H. Zu, "Research on Trajectory Generation and Optimization in Continuous Descent Operations," in 2018 Aviation Technology, Integration, and Operations Conference, American Institute of Aeronautics and Astronautics, 2018.

[23] S. Fukushima, R. Mori, and S. Saitoh, "Geometric approach for RNP transition to xLS procedure design," in 2017 IEEE/AIAA 36th Digital Avionics Systems Conference (DASC), 2017, pp. 1-8.

[24] T. Dautermann, T. Ludwig, L. Altenscheidt, R. Geister, and T. Blase, "Automatic speed profiling and automatic landings during advanced RNP to xLS flight tests," in 2017 IEEE/AIAA 36th Digital Avionics Systems Conference (DASC), 2017, pp. 1-10.

[25] C. Evertse and H. G. Visser, "Real-time airport surface movement planning: 
Minimizing aircraft emissions," Transp. Res. Part C Emerg. Technol., vol. 79, pp. 224 241, 2017.

[26] M. Weiszer, J. Chen, and G. Locatelli, "An integrated optimisation approach to airport ground operations to foster sustainability in the aviation sector," Appl. Energy, vol. 157, pp. 567-582, 2015.

[27] D. R. Jones et al., "Conducting Safe and Efficient Airport Surface Operations in a NextGen Environment," NASA Tech. Rep., no. March 2016, 2018.

[28] J. Li, G. Q. Wang, P. Zhu, X. Lu, and J. Su, "A Runway Incursion Detection Approach Based on Multiple Protected Area and Flight Status Machine for A-SMGCS," MATEC Web Conf., vol. 44, pp. 1-4, 2016.

[29] J. Liu, K. Li, M. Yin, X. Zhu, and K. Han, "Optimizing key parameters of ground delay program with uncertain airport capacity," J. Adv. Transp., vol. 2017, 2017.

[30] B. F. Santos, M. M. E. C. Wormer, T. A. O. Achola, and R. Curran, "Airline delay management problem with airport capacity constraints and priority decisions," J. Air Transp. Manag., vol. 63, no. 0, pp. 34-44, 2017.

[31] B. Park et al., "Comparison of First-Come First-Served and Optimization Based Scheduling Algorithms for Integrated Departure and Arrival Management," in 2018 Aviation Technology, Integration, and Operations Conference, American Institute of Aeronautics and Astronautics, 2018.

[32] I. Gerdes and M. Schaper, "Management of Time Based Taxi Trajectories coupling Departure and Surface Management Systems," 11th USA/Europe Air Traffic Manag. Res. Dev. Semin., 2015.

[33] H. Zhong, W. Guan, W. Zhang, S. Jiang, and L. Fan, "A bi-objective integer programming model for partly-restricted flight departure scheduling," PLoS One, vol. 13, no. 5, p. e0196146, May 2018.

[34] M. Liu, Z. Sun, X. Zhang, and F. Chu, "A two-stage no-wait hybrid flow-shop model for the flight departure scheduling in a multi-airport system," in 2017 IEEE 14th International Conference on Networking, Sensing and Control (ICNSC), 2017, pp. 495500 .

[35] W. C. Li, P. Kearney, G. Braithwaite, and J. J. H. Lin, "How much is too much on monitoring tasks? Visual scan patterns of single air traffic controller performing multiple remote tower operations," Int. J. Ind. Ergon., vol. 67, no. May, pp. 135-144, 2018.

[36] E. Dinc et al., "In-Flight Broadband Connectivity: Architectures and Business Models for High Capacity Air-to-Ground Communications," IEEE Commun. Mag., vol. 55, no. 9, pp. 142-149, 2017.

[37] J. Jeannin et al., "A Formally Verified Hybrid System for the Next-Generation Airborne Collision Avoidance System," Int. Conf. Tools Algorithms Constr. Anal. Syst., 2015.

[38] M. Strohmeier, M. Schäfer, V. Lenders, and I. Martinovic, "Realities and challenges of nextgen air traffic management: The case of ADS-B," IEEE Commun. Mag., vol. 52, no. May, pp. 111-118, 2014.

[39] Z. Wu, L. Liu, C. Yan, J. Xu, and J. Lei, "The approach of SWIM data sharing based on multi-dimensional data encryption," in 2017 25th International Conference on Software, Telecommunications and Computer Networks (SoftCOM), 2017, pp. 1-6.

[40] T. Gräupl, M. Mayr, and C. H. Rokitansky, "A Method for SWIM-Compliant Humanin-the-Loop Simulation of Airport Air Traffic Management," Int. J. Aerosp. Eng., vol. 2016, 2016.

[41] "Indonesia domestic airline market: rapid growth, rivalry intensifies," CAPA enter for Aviation, 2018. [Online]. Available: https://centreforaviation.com/analysis/reports/indonesia-domestic-airline-market-rapid- 
growth-rivalry-intensifies-410650. [Accessed: 14-Sep-2018].

[42] The Jakarta Post, "Indonesia's air traffic controllers warn of collision risks as flight volume rises," The Straits Times Singapore, 2017. [Online]. Available: http://www.straitstimes.com/asia/se-asia/indonesias-air-traffic-controllers-warn-ofcollision-risks-as-flight-volumes-rise.

[43] R. Sekartadji, E. Ahyudanari, and L. M. Jaelani, "Analysis of Air Traffic Density using GIS , Case Study: Jakarta-Surabaya Analysis of Air Traffic Density using GIS , Case Study: Jakarta-Surabaya," in The 3rd International Conference on Civil Engineering Research, 2017, no. August.

[44] Safrilah and J. C. P. Putra, "Review Study on Runway Capacity Parameters and Improvement," IOP Conf. Ser. Mater. Sci. Eng., vol. 209, no. 1, 2017.

[45] A. Atmadjati, "Bencana Alam, Tantangan Bisnis Penerbangan di Indonesia," airmagz.com, 2017. [Online]. Available: https:/www.airmagz.com/17298/bencanaalam-tantangan-bisnis-penerbangan-di-indonesia.html. [Accessed: 13-Sep-2018].

[46] P. R. Aswia et al., "OPTIMALISASI STAR RNAV 1 MENGGUNAKAN KONSEP POINT OF MERGE DI WILAYAH TERMINAL AIRSPACE BANDAR UDARA," $J$. Ilm. Aviasi Langit Biru, vol. 10, no. 2, 2015.

[47] I. Setiowati, I. Hasbiyati, and M. D. H. Gamal, "Scheduling Aircraft Landing at Single Runway," Appl. Math. Sci., vol. 11, no. 46, pp. 2265-2273, 2017.

[48] M. L. Caroline, Y. Asnar, and A. I. Kistijantoro, "Scheduling model for air traffic in Indonesia," in 2016 IEEE Region 10 Symposium (TENSYMP), 2016, pp. 83-88.

[49] S. Hamzah and S. A. Adisasmita, "Aircraft parking stands: proposed model for Indonesian airports," Procedia Environ. Sciecne, 2014.

[50] C. W. M. Noor and R. Mamat, "Application of Artificial Neural Network to Predict the use of Runway at Juanda International Airport Application of Artificial Neural Network to Predict the use of Runway at Juanda International Airport," IOP Conf. Ser. Mater. Sci. Eng., 2017.

[51] F. A. Perdana and R. Moxon, "TRAFFIC DISTRIBUTION STUDY ON MULTIAIRPORT SYSTEMS IN THE GREATER JAKARTA METROPOLITAN AREA ( GJMA ) AND ASSOCIATED IMPLICATIONS," Civ. Eng. Forum, vol. XXIII, no. January, 2014.

[52] M. I. Rachmansyah and Nahdalina, "Pengaruh Penyeimbangan Pergerakan Pesawat Terhadap Peningkatan Kinerja Bandara (Studi Kasus: Bandara Internasional SoekarnoHatta)," J. Perhub. Udar. War. Ardhia, 2017.

[53] C. Setyarini and E. Ahyudanari, "Analisis Pengaruh Pergeseran Runway Holding Position terhadap Runway Occupancy Time dan Runway Capacity (Studi Kasus: Bandar Udara Internasional Juanda)," J. Perhub. Udar. War. Ardhia, 2017.

[54] K. Novianingsih and R. Hadianti, "Modeling flight departure delay distributions," Proceeding - 2014 Int. Conf. Comput. Control. Informatics Its Appl. "New Challenges Oppor. Big Data”, IC3INA 2014, no. March 2015, pp. 30-34, 2014.

[55] A. Bharata, "Perancangan Sistem Pintar Prediksi Trajektori Pesawat Menggunakan Data ADS-B dengan Metode Kalman Filter untuk Mencegah Collision," J. Perhub. Udar. War. Ardhia, 2017.

[56] S. Nugraha and A. T. Caesar, "Analisis Kinerja Sistem Doppler VHF Omnidirectional Range dan Distance Measuring Equipment pada Navigasi Penerbangan," J. Sustain., vol. 5, no. October 2016, 2016.

[57] Y. Nurhayati and Susanti, "The Implementasion of Automatic Dependent Surveillance Broadcast ( ADS-B in Indonesia)," J. Perhub. Udar. War. Ardhia, pp. 147-162, 2014. 